\title{
Solitary Fibrous Tumor of the Orbit: A Case Report And Review of the Literature
}

\author{
Orbitanın Soliter Fibröz Tümörü: Olgu Sunumu ve Literatürün Gözden \\ Geçirilmesi
}

Ali GENC ${ }^{1}$, Zafer TOKTAS ${ }^{1}$, Coruh AZMAN¹, Suheyla UYAR BOZKURT², Turker KILIC ${ }^{1}$

${ }_{1}$ Marmara University, Institute of Neurological Sciences, Department of Neurosurgery, Maltepe, Istanbul, Turkey

${ }_{2}^{2}$ Marmara University, Institute of Neurological Sciences, Department of Pathology, Maltepe Istanbul, Turkey

Corresponding Author: Ali GENC / E-mail: draligenc@gmail.com

\begin{abstract}
Solitary fibrous tumor (SFT) is a rare, benign, spindle cell tumor that is most commonly found in the visceral pleura. The orbit is one of the most common extrapleural sites of occurrence. Though they can be seen in any age, they typically present in adults with proptosis as the prominent symptom. They show no significant gender predominance. Orbital solitary fibrous tumors routinely exhibit a benign course, but malignant forms with an increased propensity for local recurrence have been reported. Histopathologically, they share similar features with hemangiopericytoma, which is much more common. The diagnosis of SFT depends on the diffuse and intense positivity of CD34 staining by immunohistochemistry (14). Here, we report a case of SFT, which presented with proptosis and double vision on lateral gaze. We describe the clinical, radiographic, histopathological, and immunohistochemical findings. We also provide a discussion on its origin and differential diagnosis in the light of relevant literature.
\end{abstract}

KEYWORDS: Solitary fibrous tumor, Orbit, CD34

öz

Soliter fibröz tümör (SFT) nadir, selim huylu, iğsi hücreli bir tümördür ve en sıklıkla visseral plevradan kaynaklanır. Plevra dışında, en sık ortaya çıktığı yerlerden biri orbitadır. Her yaşta ortaya çıkabilir, ama en sık erişkinlerde görülür ve en belirgin semptom proptozis'dir. Önemli bir cinsiyet yatkınlığı gözetmez. Orbital SFT'ler genellikle iyi prognoz gösterirler, ama yerel rekürrense meyilli habis tümörler de bildirilmiştir. Histopatolojik olarak, daha sıklıkla karşılaşılan hemanjioperisitom ile benzer özellikleri vardır. SFT tanısı immünohistokimya çalışması ile yoğun pozitif CD34 boyanmanın gösterilmesiyle konur. Burada, proptozis ve yana bakışta çift görme şikayeti ile başvuran bir orbital SFT olgusu sunuyoruz. Klinik, radyolojik, histopatolojik ve immünohistokimyasal sonuçları anlattıktan sonra mevcut literatür ışığında, kökeni ve ayırıcı tanısına yönelik bir tartışma yapacağız.

ANAHTAR SÖZCÜKLER: Soliter fibröz tümör, Orbita, CD34

\section{INTRODUCTION}

Klemperer and Rabin first described solitary fibrous tumor (SFT) in 1931 (10). It is a rare, benign, spindle cell tumor that is most commonly found in the visceral pleura (1). The orbit is one of the most common extrapleural sites of occurrence. There have been more than 50 cases reported worldwide since its first description in the orbit in 1994 by Westra et al. (16). SFTs commonly involve the superior extraconal orbit but can occur intraconally, inferiorly, in the lacrimal gland fossa, and in the lacrimal sac area (8). Though they can be seen in any age, they mostly present in adults with proptosis as the prominent symptom. They show no significant gender predominance (14). Orbital solitary tumors routinely exhibit a benign course, but malignant forms with an increased propensity for local recurrence have been reported $(7,13)$. Histopathologically, they share similar features with hemangiopericytoma, which is much more common. The diagnosis of SFT depends on the diffuse and intense positivity of CD34 staining by immunohistochemistry (16). We report a case of SFT with a discussion on the clinical, radiographic, histopathological, and immunohistochemical findings.

\section{CASE REPORT}

A 27-year-old woman presented with complaints of right eye protrusion and double vision on left lateral gaze. Her symptoms had started subtly a year ago and had become more obvious in recent months. She had no history of trauma, and her overall medical history was unremarkable. Her physical examination was notable for a moderate exophthalmos of the right eye. No neurological deficits were noted. An ophthalmological consult was obtained at admission, which revealed a moderate exophthalmos on the right, normal visual acuity, no visual field defects and no papilledema in either eye. The light reflex and gaze conjugation were unimpaired bilaterally. 
Radiological studies were ordered. Computerized tomography (CT) scans delineated a right extraconal superolateral mass with no evidence of calcification or bone destruction. 3D CT angiography suggested a vascular nature of the mass (Figure 1A). Magnetic resonance imaging (MRI) showed a well-circumscribed, expansile soft tissue mass located above the right globe extending posterolaterally in close proximity to the optic nerve. Compression on the globe was evident; however, no obvious invasion of either the optic nerve or the adjacent ocular muscles was noted (Figures 1B, C). The lesion showed iso-intensity to gray matter on T1-weighted images and hyper-intensity on T2-weighted images. An intense homogenous contrast enhancement was obtained after gadolinium injection. A differential diagnosis of a soft tissue tumor with vascular or connective tissue origin was made.

Surgical treatment was planned. A pterional incision and orbitozygomatic craniotomy were performed. The right orbital rim and roof were removed as a single piece. Intraoperatively, the tumor had a soft, capsular texture and a vascular nature. It appeared pink and it was not lobulated. It showed extensive adhesions to surrounding muscular structures. Gross total removal was achieved by means of an ultrasonic surgical aspirator. The histological study at low power magnification showed a highly vascular solid tumor mass. The extensive network of branching dilated vessels was reminiscent of hemangiopericytoma. High power magnification showed spindle cells forming short compact fascicles arranged in a whorling pattern (Figure 2A) and a stroma with ample amount of collagen deposition. Differential diagnosis was made between a fibrous meningioma, a hemangiopericytoma, and a solitary fibrous tumor by using an immunohistochemistry (IHC) panel. The tumor stained intensely for vimentin, CD34 (Figure 2B) and CD99 and it was immunonegative for S100 protein, Epithelial Membrane Protein (EMA), BCL-2, lowmolecular-weight cytokeratin (CK), and smooth muscle actin (SMA) and desmin. No signs of anaplasia were noted. The mitotic activity was low and the Ki-67 index was calculated as 3\% (Figure 2C). A final diagnosis of solitary fibrous tumor was made. The recovery of the patient was uneventful and postoperative MRI confirmed gross total removal of the tumor (Figure 1D).

\section{DISCUSSION}

SFT is an uncommon spindle cell neoplasm, which was first recognized as a distinctive pleural lesion in 1931(10). Originally, a mesothelial origin was considered and it was, hence, named solitary fibrous mesothelioma $(10,14)$. However, an increasing number of occurrences at extra-pleural sites, the consistently negative immunoreactivity of epithelial markers, and the absence of ultrastructural mesothelial features have led to skepticism about their origin. More recently a myofibroblastic/ fibroblastic lineage has been suggested due to the strong CD34 immunoreactivity, patchy actin positivity, presence of focal intercellular junctions, and cytoplasmic dense bodies (14).

Since the first report by Westra et al. in 1994 (16), the orbit has become one of the most common sites of occurrence outside the pleura. As in our patient, painless proptosis and visual disturbances are the most likely symptoms at presentation. Exophthalmos, palpable orbital mass and decreased ocular motility have also been reported (13). The slow growing nature of the lesions frequently leads to delays in initial presentation. Radiologically, SFT of the orbit appears as a nonspecific, variably enhancing soft tissue mass (4). No imaging characteristics can differentiate SFT from other orbital tumors (4) and its vascular nature makes it easy to confuse it with cavernous hemangioma, which is the most common vascular lesion in the orbit (9).

Orbital proptosis is most commonly caused by Graves' disease. Trauma and neoplasia are the other leading causes. Mesenchymal tumors account for 5 to $8 \%$ of orbital neoplasms (14). In childhood, proptosis is most frequently caused by malignant rhabdomyosarcoma, while in adults, hemangiomas and fibrous histiocytomas are the more common primary orbital mesenchymal tumors (14).

Reports and awareness of orbital SFTs have been increasing in the last two decades. Review of archival spindle cell orbital tumors may be necessary to confirm their true incidence (14). Histologically, when faced with an orbital tumor, SFT may be difficult to diagnose because of its histological variability and rare incidence (1). SFT typically consists of monomorphic sheets of spindle cells in straight or whirling fascicles surrounded by a fibrous matrix composed of conspicuous eosinophilic bands of collagen (1). Staghorn shaped, thinwalled vessels are abundant and sometimes suggest a hemangiopericytoma-like pattern (1). The tumor in our case displayed similar characteristics, which further supported the diagnosis of the tumor as a SFT.

Hemangiopericytoma and solitary fibrous tumors have overlapping histologic features including variable degrees of CD34 reactivity (14). CD34 is a trans-membrane glycoprotein expressed by hematopoietic progenitor cells, endothelia, and certain populations of mesenchymal stromal cells in the dermis (1). In an attempt to explain the similarity of these tumors, Goldsmith et al. (5) proposed that orbital hemangiopericytomas and solitary fibrous tumors are a continuum of the same pathologic entities and when occurring in the orbit they should both be included under the rubric of solitary fibrous tumor (5). However, SFT can mimic other benign or malignant spindle cell tumors, including meningiomas. Therefore, a panel of IHC should be undertaken for a definitive diagnosis. Unlike the majority of fibrous meningiomas, hemangiopericytomas and SFTs consistently do not stain for EMA and S-100 protein (1). CD34 is generally accepted as the most sensitive marker for SFTs $(1,6)$. Therefore, the CD34 test was utilized also in our study to obtain a differential diagnosis. As in our patient (Figure 2B), a strong, diffuse CD34 staining is observed in SFTs in contrast to the patchy and weak expression observed in $33 \%$ of hemangiopericytomas (1). In addition to CD34, CD99 was utilized as a differential diagnosis marker in $\mathrm{IHC}$, since solitary fibrous tumors are classically noted to stain strongly with both CD34 and CD99 (12). The strong staining for 


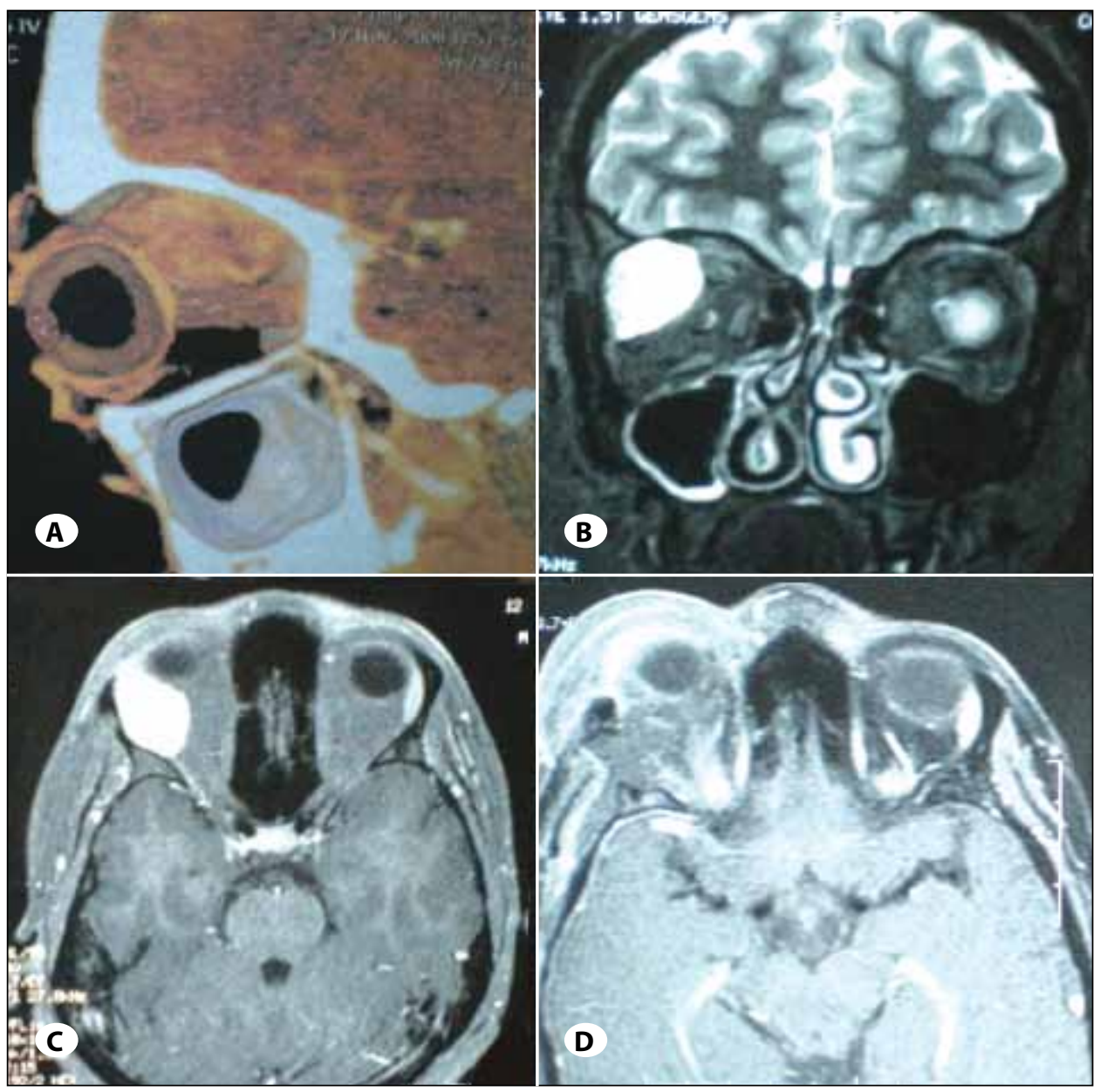

Figure 1: A) Preoperative 3D-CT image and B) preoperative $\mathrm{T} 2$ coronal C) preoperative $\mathrm{T} 1$ axial MRI demonstrate a right-sided orbital extraocular vascular mass with homogenous gadolinium enhancement. D) Postoperative T1 axial MRI confirms gross total resection of the tumor.

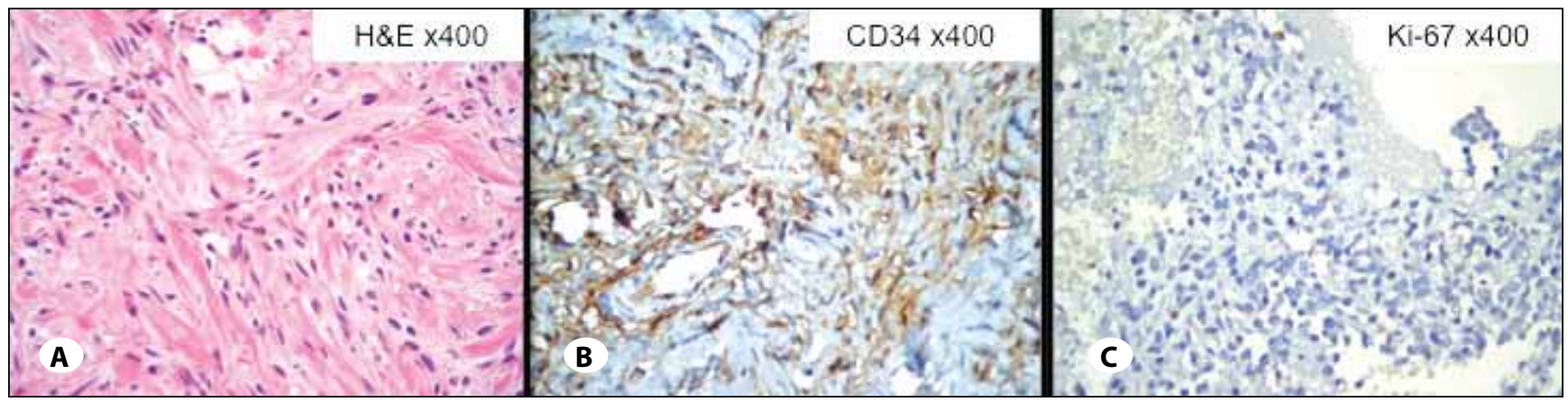

Figure 2: Histopathological study of the tumor. A) Spindle neoplastic cells forming short fascicles are seen in eosinophilic collagenous stroma (H\&E, x400). B) Widespread immunoreactivity for CD34 is noted among neoplastic spindle cells (CD34, x400). C) Ki-67 immunoreactivity is seen in $3 \%$ of the neoplastic cells (Ki-67, $x 400$ ).

both these markers further supported the diagnosis of the mass as a solitary fibrous tumor. Although focal expression of S100 protein, cytokeratin, neuron-specific enolase and progesterone receptor antibodies were reported in some of the previous studies $(5,6)$, no immunoreactivity was detected in our case. Since there are contradictory results for these markers, strong staining for CD34 and CD99 was more significant for the definitive diagnosis. The lesions have been reported to display little or no cytologic atypia and minimal mitotic activity (5). Our case report also supports these findings (Figure $2 \mathrm{C}$ ).

The review of the literature reveals an accelerating rate of reports of orbital SFTs. This is most likely due to increased awareness and widespread use of $\mathrm{IHC}$ for definitive diagnosis. Most of these reports are individual cases. Kim et al. reported the largest series with 6 cases (9). Le et al. and Tam et al. both reported series of 4 cases $(11,15)$. It seems that surgical 
resectability is the single most important determinant of outcomes for these tumors that are mostly circumscribed and amenable to complete excision (7). They generally have benign histology and behavior, as also presented in our case. However, the histological grade is not always correlated with clinical outcomes for SFTs. Despite the small number of cases reported, at least 8 cases had local relapse or distant spread following total surgical excision $(7,12)$. Bernardini et al. reported a recurrence rate of $19 \%(n=42)$ (3). Although complete surgical excision is the primary goal in such cases, it may not be always possible. There is no conclusive evidence that adjunctive radiotherapy or chemotherapy provides any benefits in the cases of residual tumors (2). Therefore, these tumors may need further surgical excision. Considering these factors, regular patient follow-up is crucial. In our case, the patient experienced no further complications (e.g. local relapse or distant spread) in the period following the operation.

In conclusion, solitary fibrous tumors of the orbit are rare tumors of mesenchymal origin for which positive staining for CD34 is the most specific diagnostic test. They generally follow a benign course and are treated definitively with surgical excision, although malignant tumors are possible. Larger series with longer follow-up will provide a better understanding of their real incidence, treatment and prognosis.

\section{REFERENCES}

1. Ahn JY, Shim JY, Yang WI, Kim TS: Meningeal solitary fibrous tumor as an unusual cause of exophthalmos: Case report and review of the literature. Neurosurgery 48(6):1362-1366, 2001

2. Ali MJ, Honavar SG, Naik MN, Vemuganti GK: Orbital solitary fibrous tumor: A race clinicopathologic correlation and review of literature. J Red Med Sci 18(6):529-531, 2013

3. Bernardini FP, de Conciliis C, Schneider S, Kersten RC, Kulwin DR: Solitary fibrous tumor of the orbit: Is it rare? Report of a case series and review of the literature. Ophthalmology 110:1441-1448, 2003
4. Festa S, Lee HJ, Langer P, Klein KM: Solitary fibrous tumor of the orbit: CT and pathologic correlation. Neuroradiology 41:52-54, 1999

5. Goldsmith JD, van de Rijn M, Syed N: Orbital hemangiopericytoma and solitary fibrous tumor: A morphologic continuum. Int J Surg Pathol 9:295-302, 2001

6. Hanau CA, Miettinen M: Solitary fibrous tumor: Histological and immunohistochemical spectrum of benign and malignant variants presenting at different sites. Hum Pathol 26:440-449, 1995

7. Hayashi S, Kurihara H, Hirato J, Sasaki T: Solitary fibrous tumor of the orbit with extraorbital extension: Case report. Neurosurgery 49:1241-1245, 2001

8. Johnson TE, Onofrey CB, Ehlies FJ: Echography as a useful adjunct in the diagnosis of orbital solitary fibrous tumor. Ophthal Plast Reconstr Surg 19: 68-74, 2003

9. Kim HJ, Kim HJ, Kim YD, Yim YJ, Kim ST, Jeon P, Kim KH, Byun HS, Song HJ: Solitary fibrous tumor of the orbit: CT and MR imaging findings. Am J Neuroradiol 29: 857-862, 2008

10. Klemperer $P$, Rabin C: Primary neoplasm of the pleura: $A$ report of five cases. Arch Pathol 11:385-412, 1931

11. Le $C P$, Jones $S$, Valenzuela $A A$ : Orbital solitary fibrous tumor: A case series with review of the literature. Orbit 33:145-151, 2014

12. Leoncini G, Maio V, Puccioni M, Franchi A, De Giorgi V, Ucci F, Santucci M, Massi D: Orbital solitary fibrous tumor: A case report and review of the literature. Pathol Oncol Res 14: 213-217, 2008

13. O'Donovan DA, Bilbao JM, Fazl M, Antonyshyn OM: Solitary fibrous tumor of the orbit. J Craniofac Surg 13: 641-644, 2002

14. Ramdial PK, Nadvi S: An unusual cause of proptosis: Orbital solitary fibrous tumor: Case report. Neurosurgery 38: 1040-1043, 1996

15. Tam ES, Chen EC, Harvey JT, Howarth D, Oestreicher JH: Solitary fibrous tumor of the orbit: A case series. Orbit 27: 426431, 2008

16. Westra WH, Gerald WL, Rosai J: Solitary fibrous tumor. Consistent CD34 immunoreactivity and occurrence in the orbit. Am J Surg Pathol 18(10):992-998, 1994 